\title{
Population Based Survey Study Associated With Prevalence Of Cardiovascular Risk Factors In India
}

\author{
Mandheer Kaur ${ }^{1 *}$, Sahil Sharma ${ }^{1}$, Chaitanayajit $\operatorname{singh}^{1}$ \\ Ankit Magotra $^{2}$, Preeti Devi ${ }^{1}$, shilpa Bhat $^{1}$, Palki Sahib Kaur ${ }^{1}$, Arockia M. Babu ${ }^{1}$ \\ 1 Chandigarh Group of Colleges, Landran, Mohali \\ 2 Lala Lajpat Rai University of Agriculture, Hisar \\ *Corresponding author
}

\begin{abstract}
The present study was conducted on 204 individuals of different regions of Chandigarh, Mohali, Panchkula, Himachal Pradesh and Haryana, India, to assess the level of knowledge and awareness of risk factors associated with cardiovascular disease (CVD) in targeted population. Population survey based study was carried out in people grouped in three age groups (Group 1: <18 years, Group 2: Between 18-40 years, Group 3: Above 40). Cardiovascular risk assessment questionnaire was used to assess the level of knowledge and awareness of risk factors via goggle forms and manually filling the same forms. Among risk factors 8.8 percent persons from our targeted population encountered with heart attack, angina, abnormal Heart Rhythm with significant hike in CVD cases was observed in group 3 individuals. Incidence of high blood pressure was observed in $32.4 \%, 4.9 \%$ are normal and $62.7 \%$ are unaware of their blood pressure status. Similarly, majority of the population $\mathbf{4 2 . 6 \%}$ are not aware of their blood cholesterol level. The participants were not aware about regular physical activity and exercise, food intake to lower risk factors for the heart disease. There is an urgent need to increase awareness among the population utilizing community based education programs.
\end{abstract}

Keywords: Cardiovascular disease, risk factors, knowledge, awareness

\section{INTRODUCTION}

Cardiovascular disease (CVD) is a major cause of heart related death worldwide [1]. This disease covers both developed as well as developing countries. In 2008, around $30 \%$ of overall mortality was due to this disease and 6.2 to 7.3 million deaths were only due to "Heart Stroke" globally. Incidence of cardiovascular disease is expected to increase by 23.3 million by 2030 [2]. Incidence of CVD is associated with a set of certain risk factors that are commonly used to assess absolute cardiovascular risk in the normal population $[3,4,5]$.

The majority of cardiovascular disease (CVD) is caused by certain risk factors that can be controlled, modified or treated [6]. However, there are some major CVD risk factors also that cannot be controlled or modified. The main risk factors for cardiovascular diseases includes smoking, bad cholesterol, high LDL, low level of HDL or good cholesterol, physical inactivity, high blood pressure, uncontrolled hypertension, stress, anger, Obesity and diabetes [7].

In last 20 years researchers observed that occurrence of above $73 \%$ of new heart disease cases were mainly due to poor lifestyle factors [8]. In the same way, poor lifestyle factors were responsible for almost half of clinical risk factors, like high cholesterol, high blood pressure and diabetes [8]. In order to reduce risk of disease, change in lifestyle is recommend as it is reported that healthy behaviors can reduces risk of disease [9].

A good knowledge of modifiable risk factors of cardiovascular disease is a pre-requisite to change the individual's behaviors and lifestyle practices [10,11]. Knowledge can improve in heart stroke symptoms and recognition of heart attack. This may lead to early presentation to medical care and hence may result in better patient's outcomes $[8,10]$. Baseline knowledge about CVD risk factors among the population play significant health application as it helps in developing different targeted educational programs [12]. There is little information known about the knowledge of CVD risk factors in the Eastern Mediterranean region [13]. The present study aimed at evaluation of current CVD knowledge and level of awareness among Chandigarh and nearby population. This study also explored public views on the role of pharmacists in prevention and management of CVD.

\section{MATERIAL \& METHODS}

\section{A. Study population:}

This study is made of data generated from baseline survey carried out in different regions of Chandigarh, Mohali, Panchkula, Himachal Pradesh and Haryana, India. The targeted population was investigated by sharing a questionnaire via google forms and manually filling the same forms. The survey provided estimates of health determinants, health status and health system. There was random selection of person from above mentioned areas. The population selected was categorized into three group based on their age i.e.

Present studies provide an update of prevalence of major and inmportant cardio vascular risk factors of Indian population. It also imparts awareness of the impact of risk factors responsible for CVD.

\section{B. Data analysis:}

Result of every questionnaire was individually checked after interview. After that the data was arranged and checked for any discrepancy Any obscure and misunderstood questionnaire was excluded from the dataset. The answers according to the questionnaire 
were entered into a computer spreadsheet, Microsoft Excel ${ }^{\circledR}$ (Microsoft Corporation, USA). Further descriptive data analysis like frequency, average and percentage were calculated by IBM SPSS-22.

\section{TABLE 1: QUESTIONNAIRE FOR CARDIOVASCULAR RISK ASSESSMENT}

CARDIOVASCULAR RISK ASSESSMENT QUESTIONNAIRE NAME : DATE :

AGE

GENDER (M/F/other):

Q.1 Have you ever been told by a doctor that you have heart disease, such as heart attack, angina, abnormal heart rhythm or other.
Yes
Don't know

Q.2 How old was you when heart disease was first diagnosed? Before 20

Between 20-40

After 40

Don't know

Q.3 Have you had a stroke during the past 12 months?

$$
\begin{aligned}
& \text { Yes } \\
& \text { No } \\
& \text { Don't know }
\end{aligned}
$$

Q4. When was the last time you had your blood pressure checked? Within the last month

Within the past 1 year (Anytime less than 12 months ago)

Within the past 5 years (more than 1 years ago but less than 5

years ago)

\section{Never had it checked}

Q5. The LAST time you had your blood pressure checked, was it normal or high?

\section{Normal}

High

Don't Know/Not Sure

Q6. Have you EVER been told by a doctor, nurse, or other health professional that you have High blood pressure?

Yes

No

Don't Know/Not Sure

Q7.Are you currently taking medicine for your high blood pressure?

Yes

No

Don't Know/Not Sure

Q8. Do you workout or exercising to improve your health?

Regularly

Once or twice a week

Very Often or Never

Q9. About how long has it been since you last had your blood cholesterol checked?

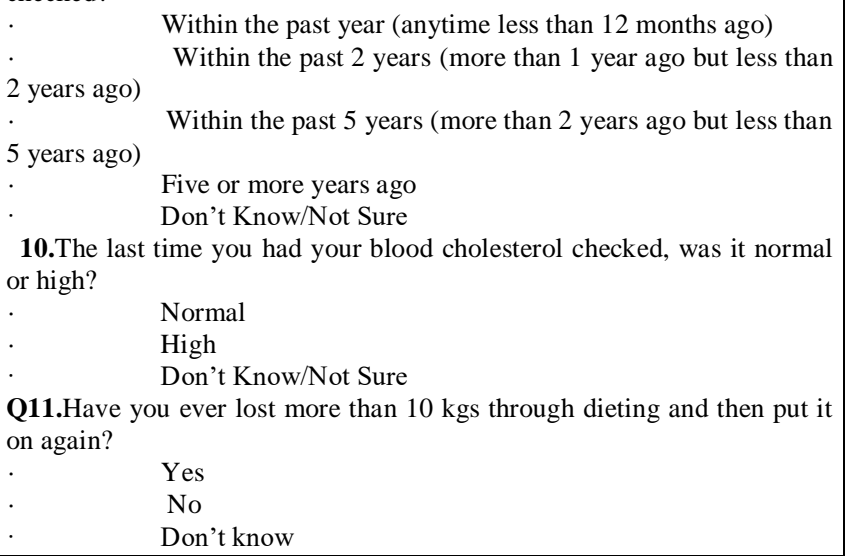

Q12. Have you ever been a regular smoker of one or more cigarettes per day?

$$
\begin{aligned}
& \text { Yes } \\
& \text { No } \\
& \text { Don't know }
\end{aligned}
$$

Q13.On average, how many servings of vegetables (fresh, frozen, canned) do you eat a day? Do not include vegetable juices. Please answer one only.

A 'serving' $=1$ medium potato/kumara or $1 / 2$ cup cooked vegetables or 1 cup of salad vegetables) e.g. 2 medium potatoes $+1 / 2$ cup of peas $=3$ servings.

$$
\begin{aligned}
& \text { I don't eat vegetables } \\
& 2 \text { servings per day } \\
& \text { Less than } 1 \text { serving per day } \\
& 3 \text { servings per day } \\
& 1 \text { serving per day } \\
& 4 \text { or more servings per day }
\end{aligned}
$$

Q14.Have you had a drink containing alcohol in the last year? Never

Less than monthly

Monthly

Weekly

Daily or almost daily

Q15.How often you consume fast food in your routine lifestyle? Never

Less than monthly

Monthly

Weekly

Daily or almost daily

\section{RESULT AND DISCUSSION:}

\section{A. Number individual participated (Sex wise):}

The survey was conducted randomly only after the given consent of the respondent among the people of targeted area. In the present study 204 people participated in the survey. Characteristics of the 204 respondent are listed in (Table 2).

TABLE 2: NUMBER OF PEOPLE PARTICIPATED IN SURVEY

\begin{tabular}{|l|c|c|}
\hline Gender & Frequency & Percentage \\
\hline Male & 91 & 44.6 \\
\hline Female & 113 & 55.4 \\
\hline Total & 204 & 100 \\
\hline
\end{tabular}

The frequency of female (55.4 percent) respondents was comparatively more than male (44.6 percent) respondents.

\section{DETREMINENT OF CVD}

\section{a) Occurrence heart attack, angina, abnormal Heart Rhythm :}

The data generated revealed that 8.8 percent persons from our targeted population encountered with heart attack, angina, abnormal Heart Rhythm. However.79.4\% are normal and $11.8 \%$ are unaware of their health status. (Table 3).

There is a large burden of undiagnosed conditions and awareness about these symptoms, uncovering which will likely be essential to making progress on better control over CVD. Studies in similar populations that rely solely on self-reported diagnoses of hypertension or diabetes may underestimate the true prevalence of these conditions. Area wise or region wise there is wide distribution of CVD risk factors in India. Diabetes mellitus appears to be more prevalent in the southern states of India, whereas hypertension appears to be higher in the northeastern states. 
TABLE 3: OCCURANCE OF HEART ATTACK, ANGINA, ABNORMAL HEART RHYTHM OR OTHER

\begin{tabular}{|l|c|c|}
\hline \multicolumn{1}{|c|}{ Option } & Frequency & Percent \\
\hline Yes & 66 & 32.4 \\
\hline No & 128 & 62.7 \\
\hline Don't Know & 10 & 4.9 \\
\hline Total & 204 & 100 \\
\hline
\end{tabular}

a) Age :

The responses collected in our survey revealed that only 1 percent of cases of CVD were reported in age group 1. In age group 2, more than 10 percent CVD cases were reported. Whereas, significant hike in CVD cases was observed in group 3 individuals. (Table.4).

\section{TABLE 4: PREVALENCE OF CVD IN DIFFERENT AGE} GROUPS

\begin{tabular}{|l|l|l|l|l|}
\hline Age & Frequency & Percent & $\begin{array}{l}\text { Valid } \\
\text { Percent }\end{array}$ & $\begin{array}{l}\text { Cumulative } \\
\text { Percent }\end{array}$ \\
\hline Below 18 & 2 & 1 & 1 & 1 \\
\hline Between 18-40 & 8 & 3.9 & 3.9 & 15.2 \\
\hline Above 40 & 21 & 10.3 & 10.3 & 11.3 \\
\hline Don't know & 9 & 4.4 & 4.4 & 19.6 \\
\hline Not Applicable & 164 & 80.4 & 80.4 & 100 \\
\hline Total & 204 & 100 & 100 & \\
\hline
\end{tabular}

Many survey based studies revealed that male , older (52 years vs 48 years) and working individuals are more cardiovascular risk factor (15).

\section{b) Incidence of Stroke:}

A stroke is when poor blood flow to the brain results in cell death. The main risk factor for stroke is high blood pressure. Other risk factors include tobacco smoking, obesity and high blood cholesterol. [19] The targeted population shows that only $3.9 \%$ were affected with the disease, $53.9 \%$ were on the safer side, $39.2 \%$ were not applicable as they don't have any kind of cardiac history and $2.9 \%$ people were unaware about any kind of trouble. (Table.5)

\begin{tabular}{|l|c|c|}
\hline \multicolumn{1}{|c|}{ TABLE 5: PREVALENCE OF INCIDENCE OF STROKE } \\
\hline Options & Frequency & Percent \\
\hline Yes & 8 & 3.9 \\
\hline No & 110 & 53.9 \\
\hline Don't know & 6 & 2.9 \\
\hline Not Applicable & 80 & 39.2 \\
\hline Total & 204 & 100 \\
\hline
\end{tabular}

\section{c) Diagnosis of High Blood Pressure:}

The incidence of high blood pressure in the targeted population revealed that $32.4 \%$ are have been diagnosed for High Blood Pressure, $4.9 \%$ are normal and $62.7 \%$ are unaware of their health status (Table.6).

\section{TABLE 6: PREVALENCE OF HIGH BLOOD PRESSURE}

\begin{tabular}{|l|c|c|}
\hline \multicolumn{1}{|c|}{ Option } & Frequency & Percent \\
\hline Yes & 66 & 32.4 \\
\hline No & 128 & 62.7 \\
\hline Don't Know & 10 & 4.9 \\
\hline Total & 204 & 100 \\
\hline
\end{tabular}

The data also revealed that the frequency of higher blood pressure persons is significantly higher in the targeted population which will further lead to hypertension and CVD. (Table 7). This preliminary data exposed that people lack awareness regarding cardio vascular disease. So, mass awareness is the pre requisite to combat CVD in more strategic way.

TABLE 7: STATUS OF BLOOD PRESSURE
\begin{tabular}{|c|c|c|c|c|}
\hline BP & Frequency & $\begin{array}{c}\text { Perce } \\
\text { nt }\end{array}$ & $\begin{array}{c}\text { Valid } \\
\text { Percent }\end{array}$ & $\begin{array}{c}\text { Cumulati } \\
\text { ve } \\
\text { Percent }\end{array}$ \\
\hline Normal & 103 & 50.5 & 50.5 & 50.5 \\
\hline High & 60 & 29.4 & 29.4 & 79.9 \\
\hline Low & 11 & 5.4 & 5.4 & 85.3 \\
\hline $\begin{array}{c}\text { Don't } \\
\text { know or } \\
\text { Not sure }\end{array}$ & 30 & 14.7 & 14.7 & 100 \\
\hline Total & 204 & 100 & 100 & \\
\hline
\end{tabular}

\section{d) Medicine Intake:}

Taking medicine of blood pressure is also symbol of unhealthy heart .In or survey, only 20 percent people are taking medicines for blood pressure (Table 8).

TABLE 8: TAKING MEDICINE TO CONTROL BLOOD PRESSURE

\begin{tabular}{|c|c|c|c|c|}
\hline \multicolumn{5}{|c|}{ Taking medicine for your high blood pressure } \\
\hline Options & Frequency & Percent & $\begin{array}{c}\text { Valid } \\
\text { Percent }\end{array}$ & $\begin{array}{c}\text { Cumulative } \\
\text { Percent }\end{array}$ \\
\hline Yes & 42 & 20.6 & 20.6 & 20.6 \\
\hline No & 161 & 78.9 & 78.9 & 99.5 \\
\hline $\begin{array}{c}\text { Don't } \\
\text { Know }\end{array}$ & 1 & 0.5 & 0.5 & 100 \\
\hline Total & 204 & 100 & 100 & \\
\hline
\end{tabular}

\section{e) Exercise status:}

In our study, 21.6 percent of candidates in population exercise regularly and 18.6 percent exercise often to maintain their health ,others 34.8 percent workout once or twice a week , 25 percent people never workout or exercise to improve their health status. This $25 \%$ percent people are more prone to CVD. (Table 9).

TABLE 9: WORKOUT OR EXERCISING TO IMPROVE YOUR HEALTH

\begin{tabular}{|l|l|l|l|l|}
\hline \multicolumn{1}{|c|}{ Options } & Frequency & Percent & $\begin{array}{c}\text { Valid } \\
\text { Percent }\end{array}$ & $\begin{array}{c}\text { Cumulative } \\
\text { Percent }\end{array}$ \\
\hline Regularly & 44 & 21.6 & 21.6 & 21.6 \\
\hline $\begin{array}{l}\text { Once or } \\
\text { twice a week }\end{array}$ & 71 & 34.8 & 34.8 & 56.4 \\
\hline Very often & 38 & 18.6 & 18.6 & 75 \\
\hline Never & 51 & 25 & 25 & 100 \\
\hline Total & 204 & 100 & 100 & \\
\hline
\end{tabular}

\section{f) Blood cholesterol check:}

Blood cholesterol is the major factor of heart diseases. Blood cholesterol levels should be checked and maintain in a normal manner. Our study revealed that, majority of the population $42.6 \%$ are not aware of their blood cholesterol level, $30.9 \%$ people have got checked since last 12 months, $18.1 \%$ got checked within past $12-24$ months and $8.3 \%$ had checked in between 2-5 years. (Table.10). Blood cholesterol should be maintained in a controlled manner to decrease the risk of CVD. Candidates in population who got it checked shows $30.4 \%$ normal results, $20.6 \%$ people 
have high level of blood cholesterol level and $49 \%$ are not sure about their blood cholesterol levels. (Table.11).

TABLE 10: BLOOD CHOLESTEROL EXAMINATION

\begin{tabular}{|l|l|l|l|l|}
\hline & Frequency & Percent & $\begin{array}{l}\text { Valid } \\
\text { Percent }\end{array}$ & $\begin{array}{l}\text { Cumulative } \\
\text { Percent }\end{array}$ \\
\hline $\begin{array}{l}\text { Within the } \\
\text { past 12 } \\
\text { months }\end{array}$ & 63 & 30.9 & 30.9 & 30.9 \\
\hline $\begin{array}{l}\text { Within the } \\
\text { past 12-24 } \\
\text { months }\end{array}$ & 37 & 18.1 & 18.1 & 49 \\
\hline $\begin{array}{l}\text { More than } \\
\text { 24 months } \\
\text { up to 5 years }\end{array}$ & 17 & 8.3 & 8.3 & 57.4 \\
\hline Never & 87 & 42.6 & 42.6 & 100 \\
\hline Total & 204 & 100 & 100 & \\
\hline
\end{tabular}

TABLE 11: LEVEL OF BLOOD CHOLESTEROL IN SURVEYED POPULATION

\begin{tabular}{|l|l|l|l|l|}
\hline Options & Frequency & Percent & $\begin{array}{l}\text { Valid } \\
\text { Percent }\end{array}$ & $\begin{array}{l}\text { Cumulative } \\
\text { Percent }\end{array}$ \\
\hline Normal & 62 & 30.4 & 30.4 & 30.4 \\
\hline High & 42 & 20.6 & 20.6 & 51 \\
\hline $\begin{array}{l}\text { Don't know } \\
\text { or Not sure }\end{array}$ & 100 & 49 & 49 & 100 \\
\hline Total & 204 & 100 & 100 & \\
\hline
\end{tabular}

\section{g) Body weight:}

Quick changes in weight in can increase the occurrence of CVD. $11.3 \%$ of our population reduced body weight in short duration, $5.9 \%$ candidates shows no vast changes in their weight and $82.8 \%$ are not aware about any changes in their weight.(Table.12)

TABLE 12: BODY WEIGHT LOST MORE THAN 10 KGS THROUGH DIETING AND THEN PUT IT ON AGAIN

\begin{tabular}{|c|c|c|c|c|}
\hline Options & Frequency & Percent & $\begin{array}{c}\text { Valid } \\
\text { Percent }\end{array}$ & $\begin{array}{c}\text { Cumulative } \\
\text { Percent }\end{array}$ \\
\hline Yes & 23 & 11.3 & 11.3 & 11.3 \\
\hline No & 169 & 82.8 & 82.8 & 94.1 \\
\hline Don't Know & 12 & 5.9 & 5.9 & 100 \\
\hline Total & 204 & 100 & 100 & \\
\hline
\end{tabular}

\section{h) Smoking habit:}

In our study we observed frequency of regular smoker of one or more cigarettes per day the data revealed that 90 $\%$ percent of the surveyed population is non smokers. Only 9.3\% are regular smokers.(Table.13).

\section{TABLE 13: STATUS OF REGULAR SMOKER OF ONE OR} MORE CIGARETTES PER DAY

\begin{tabular}{|l|l|l|l|l|}
\hline Options & Frequency & Percent & $\begin{array}{c}\text { Valid } \\
\text { Percent }\end{array}$ & $\begin{array}{c}\text { Cumulative } \\
\text { Percent }\end{array}$ \\
\hline Yes & 19 & 9.3 & 9.3 & 9.3 \\
\hline No & 185 & 90.7 & 90.7 & 100 \\
\hline Total & 204 & 100 & 100 & \\
\hline
\end{tabular}

\section{i) Alcohol intake:}

Intake of alcohol in an excess amount can increase the risk of heart attack or CVD. In our resource population intake of alcohol is on the higher side i.e 75.5 percent population intake alcohol regularly (daily or weekly). 14.7 percent on monthly routine and 11.3 percent consume it on a less then monthly basis.(Table.14).

Table 14: Status of Alcohol intake

\begin{tabular}{|c|c|c|c|c|}
\hline \multicolumn{5}{|c|}{ Drink Containing Alcohol In The Last Year } \\
\hline Options & Frequency & Percent & $\begin{array}{c}\text { Valid } \\
\text { Percent }\end{array}$ & $\begin{array}{c}\text { Cumulative } \\
\text { Percent }\end{array}$ \\
\hline $\begin{array}{c}\text { Less than } \\
\text { monthly }\end{array}$ & 23 & 11.3 & 11.3 & 11.3 \\
\hline Monthly & 30 & 14.7 & 14.7 & 26 \\
\hline Weekly & 148 & 72.5 & 72.5 & 98.5 \\
\hline $\begin{array}{c}\text { Daily or } \\
\text { almost daily }\end{array}$ & 3 & 1.5 & 1.5 & 100 \\
\hline Total & 204 & 100 & 100 & \\
\hline
\end{tabular}

\section{j) Intake of balance diet :}

Healthy and balanced diet is very essential for good health and to combat stress. Unbalanced diet can have severe effect on a human body. Our study showed that 37 percent of our recourse population consume food only one time in a day, 47.7 percent consume 2 servings per day, $8.3 \%$ can consume upto 3 servings per day, while $8.3 \%$ shows that they don't consume vegetables in their daily lifestyle. (Table 15)

TABLE 15: CONSUMPTION OF VEGETABLES PER DAY

\begin{tabular}{|c|c|c|c|c|}
\hline Options & Frequency & Percent & $\begin{array}{c}\text { Valid } \\
\text { Percent }\end{array}$ & $\begin{array}{c}\text { Cumula } \\
\text { tive } \\
\text { Percent }\end{array}$ \\
\hline $\begin{array}{c}\text { I don't eat } \\
\text { vegetables }\end{array}$ & 17 & 8.3 & 8.3 & 8.3 \\
\hline $\begin{array}{c}\text { Less than 3 } \\
\text { servings }\end{array}$ & 17 & 8.3 & 8.3 & 16.7 \\
\hline 1 serving per day & 85 & 41.7 & 41.7 & 58.3 \\
\hline 2 serving per day & 77 & 37.7 & 37.7 & 96.1 \\
\hline $\begin{array}{c}\text { 4 or more serving } \\
\text { per day }\end{array}$ & 8 & 3.9 & 3.9 & 100 \\
\hline Total & 204 & 100 & 100 & \\
\hline
\end{tabular}

Now days the quick change in a lifestyle can be observed and in between this, the place of nutritious diet is quickly replacing it by fast food diet. It is a food which contains some deliciousness but similarly it is an invitation to many kind of diseases like obesity, hypertension, heart attacks etc. In our survey, the responses achieved interprets that 33.8 percent of our added fast food in their monthly food intake whereas, $10.3 \%$ less than monthly and more than 50 percent consume fast food on a daily or weekly basis (Table.16). This first hand information is very worrisome and there is an urgent need to create awareness among individuals about healthy lifestyle.

TABLE 16: CONSUMPTION OF FAST FOOD IN ROUTINE LIFESTYLE

\begin{tabular}{|l|c|c|l|c|}
\hline Options Frequency & Percent & $\begin{array}{l}\text { Valid } \\
\text { Percent }\end{array}$ & $\begin{array}{l}\text { Cumulative } \\
\text { Percent }\end{array}$ \\
\hline $\begin{array}{l}\text { Less than } \\
\text { monthly }\end{array}$ & 21 & 10.3 & 10.3 & 10.3 \\
\hline Monthly & 69 & 33.8 & 33.8 & 44.1 \\
\hline Weekly or & 85 & 41.7 & 41.7 & 85.8 \\
\hline $\begin{array}{l}\text { Daily } \\
\text { almost daily }\end{array}$ & 29 & 14.2 & 14.2 & 100 \\
\hline Total & 204 & 100 & 100 & \\
\hline
\end{tabular}

There is a large burden of undiagnosed angina, abnormal heart rhythm, hypertension, stroke uncovering which will likely be essential to making progress on better control of CVD. We also observed in our study that most 
people aware of their diagnosis of, hypertension, and stroke are on treatment but there is a lack of awareness among individual regarding signs and symptoms associated with CVD which could possibly explain the gap in a substantial manner. Similar studies have been reported in a community in West Bengal, India [15]. Cardiovascular disease (CVD) is the reason for a large proportion of all deaths and disability worldwide. CVDs are the number one cause of death globally [16].

Rapid urbanization in our country, with more than 31 percent of Indians living in urban areas and the decadal shift of rural people toward urban areas, has led to a number of issues like reduced physical activity, unhealthy food habits, unhygienic, mental /physical stress, and higher exposure to pollution [17]. The nutritional shift has moved a number of people to unhealthy eating habits. In our study also majority of the population not following health and nutritious food habits and shifted more towards junk foods. Thus proper extension and awareness at gross route level is the pre requisite.

Serum cholesterol were associated with a significantly increased prevalence of CVD. Some studies in Indian reported the risk of CVD rises progressively with increases in serum cholesterol level $>150 \mathrm{mg} / \mathrm{dl}$ $(3.89 \mathrm{mmol} / \mathrm{L})[18,19,20]$. In our study majority of the population was not aware about their Cholesterol level revealed their unawareness about risk factors associated with CVD.

\section{CONCLUSION:}

Cardiovascular disease is the leading cause of mortality in India. In present we observed that majority of the people in our resource population was not aware of risk factors associated with CVD, that can be controlled, treated or modified, such as high blood pressure, cholesterol, overweight/obesity, tobacco use, lack of physical activity and diabetes. This first hand information is very worrisome and there is an urgent need to create awareness among individuals about different indicators , test (biochemical / molecular) associated with CVD and adopt healthy life style.

\section{REFERENCES}

[1]. Benjamin EJ, Blaha MJ, Chiuve SE, et al. Heart Disease and Stroke Statistics-2017 Update: a report from the American Heart Association. Circulation. 2017;135(10):e146-e603.

[2]. Prospective Studies Collaboration. Age-specific relevance of usual blood pressure to vascular mortality: a metaanalysis of individual data for one million adults in 61 prospective studies. Lancet. 2002;360(9349):1903-13.

[3]. DeFilippis AP, Young R, Carrubba CJ, et al. An analysis of calibration and discrimination among multiple cardiovascular risk scores in amodernmultiethnic cohort.Ann InternMed. 2015;162(4):266-75.

[4]. Damen JA, Hooft L, Schuit E, et al. Prediction models for cardiovascular disease risk in the general population: systematic review. BMJ. 2016;353:i2416.

[5]. Hajifathalian K, Ueda P, Lu Y, et al. A novel risk score to predict cardiovascular disease risk in national populations (Globorisk): a pooled analysis of prospective cohorts and health examination surveys. Lancet Diabetes Endocrinol. 2015;3(5):339-55.
[6]. Rao Kondapally Seshasai S, Kaptoge S, Thompson A, et al; Emerging Risk Factors Collaboration. Diabetes mellitus, fasting glucose, and risk of cause-specific death. N Engl J Med. 2011;

[7]. Lewington S, Whitlock G, Clarke R, et al; Prospective Studies Collaboration. Blood cholesterol and vascular mortality by age, sex, and blood pressure: ameta-analysis of individual data from 61 prospective studies with 55,000 vascular deaths. Lancet. 2007;370(9602):1829-1839.

[8]. Goldstein JL, Brown MS. Molecular medicine. The cholesterol quartet. Science. 2001 May 18; 292(5520):1310-2. Citation on PubMed: https://www.ncbi.nlm.nih.gov/pubmed/11360986

[9]. Jousilahti P, Laatikainen $\mathrm{T}$, Peltonen $\mathrm{M}$, Borodulin $\mathrm{K}$, Männistö S, Jula A, Salomaa V, Harald K, Puska P, Vartiainen E. Primary prevention and risk factor reduction in coronary heart disease mortality among working aged men and women in eastern Finland over 40 years: population based observational study. bmj. 2016 Mar 1;352:i721.

[10]. Defesche JC. Low-density lipoprotein receptor--its structure, function, and mutations. Semin Vasc Med. 2004 Feb;4(1):5-11. Review. Citation on PubMed: https://www.ncbi.nlm.nih.gov/pubmed/15199428

[11].Eagle, K.Coronary artery disease in India: challenges and opportunities. Lancet 2008; 371:1394-5

[12].Hobbs HH, Leitersdorf E, Leffert CC, Cryer DR, Brown MS, Goldstein JL. Evidence for a dominant gene that suppresses hypercholesterolemia in a family with defective low density lipoprotein receptors. J Clin invest. 1989; 84:656-664. [PubMed: 2760205].

[13].Prevention and Control of Diabetes, Cardio-vascular Diseases and Stroke (NPCDS) Pilot Program launched. [2010 Feb 04]

[14]. Anjana RM, Ali MK, Pradeepa R, Deepa M, Datta M, Unnikrishnan R, Rema M, Mohan V. The need for obtaining accurate nationwide estimates of diabetes prevalence in India - rationale for a national study on diabetes.Indian J Med Res. 2011; 133:369-38

[15]. Aditya Khetan, Melissa Zullo, Vittal Hejjaji, Dweep Barbhaya, Sushil Agarwal, Rishab Gupta, Sri Krishna Madan Mohan, and Richard Josephson (2017) Prevalence and pattern of cardiovascular risk factors in a population in India. Heart Asia. 9(2): e010931.

[16].Nag T and Ghosh A (2013) Cardiovascular disease risk factors in Asian Indian population: A systematic review. J Cardiovasc Dis Res. Dec; 4(4): 222-228.

[17].World Development Indicators, World Bank. http://data.worldbank.org/data-catalog/World-developmentindicators?cid=GPD_WDI.

[18].McKeigue P.M., Shah B., Marmot M.G. Relation of central obesity and insulin resistance with high diabetes prevalence and cardiovascular risk in South Asians. Lancet. 1991;337:382-386

[19].Beegom R., Singh R.B. Prevalence of coronary artery disease and its risk factors in the urban population of South and North India. Act Cardiol. 1995;50:227-240.

[20].Mckeigue P.M., Marmot M.G., Adelstein A.M. Diet and risk factors of coronary artery disease in Asians in northwest London. Lancet. 1985:1086-1090 